\title{
The San Francisco Estuary Institute Collection at the NIST Biorepository
}

\author{
Debra Ellisor \\ Nina Buzby \\ Michael Weaver \\ Melissa Foley \\ Rebecca Pugh
}




\title{
The San Francisco Estuary Institute Collection at the NIST Biorepository
}

\author{
Debra Ellisor \\ Rebecca Pugh \\ National Institute of Standards and Technology \\ Material Measurement Laboratory \\ Hollings Marine Laboratory \\ Charleston, SC 29412 \\ Nina Buzby \\ Michael Weaver \\ Melissa Foley \\ San Francisco Bay Estuary Institute \\ 4911 Central Avenue \\ Richmond, CA 94804
}

This publication is available free of charge from: https://doi.org/10.6028/NIST.IR.8370

April 2021

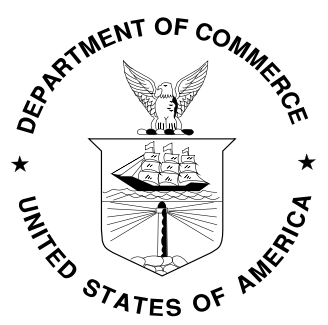

U.S. Department of Commerce Gina M. Raimondo, Secretary

National Institute of Standards and Technology James K. Olthoff, Performing the Non-Exclusive Functions and Duties of the Under Secretary of Commerce for Standards and Technology \& Director, National Institute of Standards and Technology 
Certain commercial entities, equipment, or materials may be identified in this document in order to describe an experimental procedure or concept adequately. Such identification is not intended to imply recommendation or endorsement by the National Institute of Standards and Technology, nor is it intended to imply that the entities, materials, or equipment are necessarily the best available for the purpose.

National Institute of Standards and Technology Interagency or Internal Report 8370

Natl. Inst. Stand. Technol. Interag. Intern. Rep. 8370, 22 pages (April 2021)

This publication is available free of charge from: https://doi.org/10.6028/NIST.IR.8370 


\begin{abstract}
The National Institute of Standards and Technology (NIST) has been collaborating with the San Francisco Estuary Institute (SFEI) since 2009, providing biobanking services at the NIST Biorepository in Charleston, South Carolina, in support of their ongoing water quality monitoring program, the Regional Monitoring Program for Water Quality in the San Francisco Bay (RMP). Specimens (bivalve tissue, bird egg contents, fish tissue and sediment) are collected and processed by SFEI-partnering institutions according to their established protocols and shipped to the NIST Biorepository for archiving. This report outlines NIST's role in the project, describes collection and processing protocols developed by SFEI and their collaborators, details shipping and archival procedures employed by biorepository staff and provides an inventory of the collection maintained by NIST from 2009 to 2020 .
\end{abstract}

\title{
Key words
}

Biobanking, specimens, SFEI, protocols. 


\section{Table of Contents}

1 The San Francisco Estuary Institute Project 1

1.1 Background and Responsibilities

1.2 Projected Collections

2 Preparing for a Collection 2

2.1 Supplies

2.2 Permits

3 Field Collection and Sample Processing 3

3.1 Bivalves

3.2 Sediment

3.3 Seabird Eggs

3.4 Sport fish

4 Shipment and Archival

4.1 Sample Shipment

4.2 Sample Archiving

5 Collection Inventory

References

\section{List of Tables}

Table 1. SFEI Projected Project Plan 8

Table 2. Solvent Wash Protocol 9

Table 3. Sampling Sites for RMP Bivalve Monitoring 9

Table 4. Sampling Sites for RMP Seabird Egg Monitoring 10

Table 5. Sampling Information for Sport Fish Monitoring 11

Table 6. Summary of SFEI Specimens Archived at the NIST Biorepository 13

\section{List of Figures}

$\begin{array}{lll}\text { Fig. } 1 & \text { SFEI collaborators and responsibilities } & 14\end{array}$

Fig. 2 Cryovial with barcode label appropriately applied 14

Fig. 3 PFA jar lid tab with barcode label appropriately applied 
Fig. 4 PFA jar with barcoded tab appropriately inserted into the lid 


\section{THE SAN FRANCISCO ESTUARY INSTITUTE PROJECT}

\subsection{Background and Responsibilities}

The San Francisco Estuary Institute (SFEI) is a non-profit research institute in Richmond, California that administers the Regional Monitoring Program for Water Quality in the San Francisco Bay (RMP). The RMP was created in 1993 through San Francisco Bay Regional Water Quality Control Board Resolution No. 92-043 that directed the Executive Officer to implement a Regional Monitoring Plan in collaboration with permitted dischargers pursuant to California Water Code, Sections 13267, 13383, 13268 and 13385. The goal was to replace individual receiving water monitoring requirements for dischargers with a comprehensive Regional Monitoring Program. As such, the RMP has been collecting and archiving tissue and sediment samples for retrospective chemical analyses to assess water quality in San Francisco Bay and surrounding areas.

Prior to 2010, these samples had been stored at $-20{ }^{\circ} \mathrm{C}$ at SFEI and collaborator facilities. However, reports from other research groups indicated that a storage temperature of $-20{ }^{\circ} \mathrm{C}$ may not be suitable for the long-term (>10 years) stability of chemical contaminants in these samples. Storage at $-80{ }^{\circ} \mathrm{C}$ or lower is recommended, with storage at cryogenic temperatures $\left(\leq-150{ }^{\circ} \mathrm{C}\right)$ believed to allow sample preservation without any major structural or biochemical changes over several decades [1],[2]. Since 2010, the National Institute of Standards and Technology (NIST) has been providing banking services to SFEI for long-term archiving of biological and environmental specimens at the NIST Biorepository located in the Hollings Marine Laboratory, Charleston, South Carolina. These services include:

1. Providing clean storage containers for sample collection, which include both $22 \mathrm{~mL}$ perfluoroalkoxy (PFA) jars and $5 \mathrm{~mL}$ or $10 \mathrm{~mL}$ polypropylene cryovials

2. Providing pre-printed barcode labels according to information obtained from SFEI or SFEI-affiliated field collectors for sample tracking in the NIST Biorepository database

3. Providing long-term archival of samples in liquid nitrogen vapor-phase freezers and maintaining samples according to NIST Biorepository standard operating procedures

4. Shipping samples banked from SFEI-administered programs to testing laboratories upon request

5. Maintaining an electronic database of SFEI samples, including sample identification information and sample location tracking information

A 25-year plan was developed for service from 2009-2034 (Table 1). Though the collaboration began in 2010, the previous year's collection (2009) was incorporated into the NIST Biorepository as well. Every five years, the agreement is revisited by both NIST and SFEI and the terms agreed upon. If changes are made during the span of the five-year agreement, amendments are drafted and included to incorporate changes in collection, funding or other necessary details. 


\subsection{Projected Collections}

The RMP is responsible for the collection of bivalve, bird egg, sediment and sport fish specimens. SFEI also collects sport fish specimens for the California Surface Water Ambient Monitoring Program (SWAMP), which are included in the archive. Collections are conducted by SFEI or their associated contractors according to protocols developed within their institution. Details regarding each archived collection are outlined below, including projected plans for SFEI collections. Deviations from these plans can occur for various reasons and are addressed on a case-by-case basis. Current sampling schemes are described by component below.

- Bivalves, including mussels (Mytilus californianus) are collected from a reference site and deployed for about 100 days at seven fixed locations. Native clams (Corbicula fluminea) are collected from two sites synoptically with mussel deployments. Bivalve collection frequencies have varied over time.

- Double-crested cormorant (Phalacrocorax auritus) eggs are collected from three fixed sites and Forster's tern (Sterna forsteri) eggs from a variable number of sites every three years.

- Sediment was historically collected every four years from 27 subtidal locations (seven fixed sites, 20 random sites). The frequency of subtidal collections decreased to every ten years starting in 2018. Sediment samples from the Bay margins were collected in 2015 and 2017 from 40 locations each year. Bay margins collections will continue to be collected every four years.

- Five to 15 sport fish species are collected from seven popular fishing locations every five years.

- Other SFEI programs, such as SWAMP, have also been included in the collection.

The key contacts and collaborators for each collection are outlined in Figure 1.

\section{PREPARING FOR A COLLECTION}

Prior to each collection event, SFEI contacts the NIST Biorepository to notify them of upcoming events and requests clean supplies and labels for shipment to the appropriate collaborator.

\subsection{Supplies}

NIST is responsible for receiving storage containers purchased by SFEI, cleaning these containers and shipping them to field collectors prior to each collection event. Because the main objective of the SFEI collections is to monitor a range of environmental pollutants that have different chemical properties, two different storage container types were chosen at the inception of the collaboration with NIST in order to prevent sample contamination and accommodate various downstream analyses. Samples are stored in either $22 \mathrm{~mL}$ PFA jars or polypropylene cryovials (either $5 \mathrm{~mL}$ or $10 \mathrm{~mL}$ volumes). Polypropylene cryovials are purchased sterile directly from the manufacturer. PFA jars and their accompanying recessed lids are cleaned at the NIST Biorepository using a standard solvent wash protocol (Table 2). 
Prior to each collection, sample information is provided to the NIST Biorepository to facilitate labeling of specimens in the field and ensure proper identification. This information includes, but is not limited to, a field ID, the species and common name (in the case of sport fish and egg content collections) and other identification information. This data is entered into the Biorepository's electronic sample tracking database and adhesive barcode labels are printed and shipped to the appropriate field collectors along with the clean storage containers. During sample processing the field collector adheres the aliquot label onto the appropriate sample container. Barcode labels are applied to the cryovials so that the clear portion of the label wraps around the printed portion (Figure 2). This helps ensure the label remains adhered to the vial once stored cryogenically. To effectively label PFA jars, small cardboard tabs are provided. The label is adhered to the tab ensuring the barcode is fully visible, with the clear portion of the label wrapped around the tab (Figure 3). The tab is then inserted into the recessed portion of the lid to fit tightly (Figure 4).

\subsection{Permits}

All required permits are submitted and maintained by SFEI and/or their collection partners. United States Fish and Wildlife Service (USFWS) permits are required for the take, transport and possession of bird egg specimens and various state permits are required for the capture and sacrifice of sport fish and the collection of bivalves for research.

\section{FIELD COLLECTION AND SAMPLE PROCESSING}

Each sample type that is part of SFEI efforts is collected according to a specific protocol developed and modified as necessary by SFEI and their collaborators. Field collection and processing procedures specific to each sample type are outlined below.

\subsection{Bivalves}

Mussels

Applied Marine Science (AMS) is responsible for harvesting approximately 2000 coastal mussels (Mytilus californianus) biennially from a low-contaminant site near Bodega Head State Marine Reserve and deploying them at seven sites in San Francisco Bay to measure uptake of organic and inorganic contaminants as an indicator of food web bioaccumulation (Table 2).

Adult mussels (55 to $65 \mathrm{~mm}$ in size) are targeted for collection in May or June of a sampling year and removed from the beds using an oyster knife. After harvesting, mussels are placed in buckets and transferred to free-flowing tanks containing filtered seawater at the Bodega Marine Lab for a one to two- week period of depuration, which includes removing encrusting organisms attached to the mussels. Mussels are then transported to AMS in preparation for an approximately 100-day deployment. One additional set of mussel samples are processed and stored as a control, representing the pre-deployment (T-0) condition from the Bodega Head harvesting location.

From the onset of the program until 2016, deployment and retrieval activities were conducted 
by SCUBA divers who affixed bivalve cages to United States Coast Guard Aids to Navigation or privately-owned piles. In 2018, due to known failure of the piles, the RMP moved to deployment and retrieval using weighted containment cages deployed from vessels and retrieved using acoustic releases. The seven sites targeted for deployment are shown in Table 3.

Subcontractor laboratories, hired through the RMP, process and prepare bivalves into sample homogenates by removing the shell and blending tissue from multiple individuals using a stainless-steel wand blender. The mass from the homogenate is apportioned into containers for the different analyses and archives. Archived samples are specifically collected as a split from the organics homogenate. Once storage containers have been filled and labeled, the jars and vials are stored at $-80{ }^{\circ} \mathrm{C}$ until shipment on dry ice.

\section{Clams}

AMS is also responsible for collecting approximately 600 resident freshwater clams (Corbicula fluminea) in October of the sampling year from the lower Sacramento and San Joaquin Rivers for bioaccumulation studies (Table 3). Clams are collected using a benthic dredge deployed from a vessel and dragged as slowly as possible along the river bottom. When the dredge is brought to the surface, all collected material is dumped into a pre-cleaned cooler where the viable clams are separated, placed in clean plastic bags and immediately frozen on dry ice. Subcontractor laboratories process, prepare, bottle, label and ship homogenates as previously described for the mussels.

\subsection{Sediment}

Subtidal sediments, collected by AMS, and margins sediments, collected by the Marine Pollution Studies Lab at Moss Landing Marine Labs (MPSL-MLML), are sampled from various sites in the San Francisco Bay using a $0.1 \mathrm{~m}^{2}$ modified Van Veen sediment grab sampler deployed from a vessel. The grab is constructed entirely of stainless-steel and the jaws and doors are coated with Kynar to improve chemical inertness. Using the Van Veen, a minimum of two acceptable sediment grabs are composited. The scoop and bucket used to remove and composite sediments are constructed of Kynar-coated stainless-steel, polyethylene, or polycarbonate depending on the contaminants being analyzed. For analysis of chemical constituents, samples of bulk surficial sediments (top $5 \mathrm{~cm}$ ) are collected in a manner such that surface layers are not disrupted when removed for processing.

Depending on the intended analysis, the samples are collected either directly from the grab using appropriate, non-contaminating equipment, or after the compositing process. Once a sufficient volume of subtidal sediment is collected, the Kynar-coated compositing bucket and scoops are transferred into the vessel cabin and the doors closed for processing to minimize potential vessel exhaust contamination. For the margins sediment, samples are composited in polycarbonate tubs on the open deck of the boat.

Sediment sample material in the compositing containers is mixed using Kynar-coated stainless-steel scoops until achieving a consistent appearance. While conducting mixing, sampling personnel avoid scraping the coated bucket in the interest of maintaining the 
coating's integrity. Portions of the composited sample are then aliquoted into storage containers provided by each laboratory and labeled as previously described. The exteriors of the sample containers are wiped clean of excess sediment and samples are transferred to cold storage for shipment to the biorepository on dry ice.

\subsection{Seabird Eggs}

The United States Geological Survey Western Ecological Research Center (USGS-WERC) is responsible for collecting bird eggs for downstream analysis of mercury, selenium, polychlorinated biphenyls (PCBs), polybrominated diphenyl ethers (PBDEs) and per- and polyfluoroalkyl substances (PFAS) in egg content tissue every three years. Approximately 63 cormorant eggs are collected from up to three locations and approximately 84 tern eggs are collected from up to four locations for analysis (Table 4), though total numbers may vary. A small number of these eggs may be analyzed individually for environmental contaminants, however the majority are combined together to generate composite samples.

Eggs are collected according to established protocols [3], tagged with a unique ID and transported on wet ice to the USGS-WERC. Tern eggs are processed at USGS-WERC, while cormorant eggs are shipped at room temperature to SGS AXYS Analytical Services Ltd. for processing according to established protocols. (Of note and beginning in 2021, all seabird eggs will be processed at USGS-WERC.) Briefly, egg morphometrics are documented, including egg weight, length and width. Egg contents are homogenized individually and, if requested, a portion of the homogenate is bottled for analysis. The remaining homogenate is collected in a clean stainless-steel bowl. Each egg is homogenized the same way in turn, and the homogenate from each is added to the stainless-steel bowl. This composite sample is then thoroughly mixed and aliquoted into $22 \mathrm{~mL}$ PFA jars or polypropylene cryovials and labeled appropriately. All specimens are frozen immediately and shipped on dry ice to either the appropriate analytical laboratory or to the NIST Biorepository for archival.

\subsection{Sport Fish}

Historically, the RMP, in collaboration with the MPSL-MLML and the California Department of Fish and Wildlife (CDFW), has been responsible for the collection of various species of sport fish (Table 5). Collections occur every five years for long-term biomonitoring of historically relevant organic and inorganic contaminants (e.g., pesticides, mercury) and identification of previously unknown contaminants. Species are chosen for their ability to serve as indicator species for water quality guidelines and the need for data to support the Office of Environmental Health Hazard Assessment (OEHHA) Bay fish consumption advisory.

Collection methods vary based on the species being targeted, but include otter trawls (> 50 $\%$ ), hook and line fishing $(\approx 20 \%)$, gill nets $(\approx 15 \%)$, beach seines/cast nets $(\approx 10 \%)$ and spearfishing $(<5 \%)$. Details regarding each method of collection are outlined below.

- Otter trawl collections: Trawling is the predominant method used to collect target fish species. Target species that meet size requirements are kept for chemical analyses and remaining fish are immediately released. The target fish are struck with a plastic or 
wooden mallet to euthanize them prior to placing them on dry ice.

- Hook and line collections: Various types of tackle and gear are used for hook and line fishing, depending on the targeted species and where fish are being collected (e.g., boat, pier, shoreline).

- Gill nets: Gill nets are used as a last resort, as they allow for the greatest amount of potential bycatch. Mesh size is chosen specifically to target the desired species and the nets are pulled behind the boat for a limited amount of time (a few hours) to limit the amount of bycatch.

- Beach seines: This method is used for fish that inhabit nearshore shallow areas. One sampler stands on the shoreline while another pulls the seine in a horseshoe-shaped path in the water and back to shore. Target species are picked out and others are immediately released.

- Cast nets: Also used for targeting fish in shallow areas, cast nets are tossed with the complete net opening (the weighted edges) striking the surface of the water. The weighted end sinks, entrapping the fish inside the net. As the net is pulled to the surface, the weighted edges come together, allowing the net to fully encircle the fish. Once the entire net is brought up, the targeted fish are quickly collected and others are immediately released.

- Spearfishing: This technique may be required for bottom dwelling species and is highly selective. After a fish is speared, if it is still alive, a blunt tool is used to euthanize it under water.

Approximately $150 \mathrm{~g}$ of tissue is required depending on the analytical application targeted. In order to minimize the risk of sample contamination, fish are handled only with noncontaminating gloves and wrapped in trace cleaned fluorinated ethylene propylene (FEP) sheets or aluminum foil, avoiding all contact with other field gear. Muscle is dissected from the fish in an ISO Class II laboratory clean room so that the exposure of the tissues to contaminants is minimized. MPSL-DFW dissects and homogenizes composite fish tissue samples according to established protocols. Briefly, fish within the same size class are used to create a composite sample and equal masses from each individual fish are included. The length of the smallest fish in the composite should be no less than $75 \%$ of the length of the largest fish. The majority of samples are processed as muscle fillets with the skin off. Species that are too small to be filleted are processed whole but with head, tail, and viscera removed. Composite samples are then mechanically homogenized, aliquoted into PFA jars and polypropylene cryovials and labeled appropriately before shipment to the NIST Biorepository on dry ice.

\section{SHIPMENT AND ARCHIVAL}

\subsection{Sample Shipment}

Following each collection event and before shipment, field collectors should ensure that the outside of all sample collection containers are wiped clean of extraneous debris. Collaborators are then responsible for packing all samples in coolers on blue or dry ice and shipping them to the following address: 


\author{
NIST Biorepository \\ Hollings Marine Laboratory \\ 331 Fort Johnson Road \\ Charleston, SC 29412
}

Shipments should be coordinated with NIST Biorepository staff, ensuring they can be received in a timely manner to prevent thawing of the samples. An inventory or chain of custody and any unused barcode labels should also be included in the shipment.

\title{
4.2 Sample Archiving
}

Upon receipt, the frozen samples are archived in liquid nitrogen vapor phase freezers $(\leq-150$ ${ }^{\circ} \mathrm{C}$ ). Barcode labels are scanned into the biorepository's electronic sample-tracking database and each sample is assigned a storage position. This position, the date of receipt and recipient name is also recorded. Any inventory or chain of custody sent with the shipment is crosschecked with the samples received, initialed, dated and retained in the biorepository's records. This inventory can also be used to update additional data fields in the sample-tracking database, including date and time of collection, site identification or location information, and field collector. In the case of discrepancies or shipping-associated issues, NIST Biorepository staff communicates directly with the field collector and/or SFEI personnel to ensure a resolution is reached and the integrity of the sample and data remains intact.

\section{COLLECTION INVENTORY}

The current SFEI collection inventory can be obtained through the following link (password required), while a summary of the collection is provided in Table 6 . The summary table includes data from all samples received at the NIST Biorepository from 2009 through 2020. Collection inventories with specfic inclusion/exclusion criteria can be provided to partners upon request via email to the NIST Biorepository staff. 
Table 1: Actual (2009-2020) and Estimate (2021-2033) of SFEI Collections

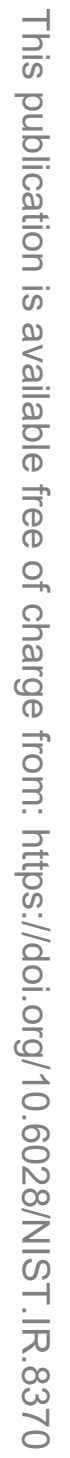

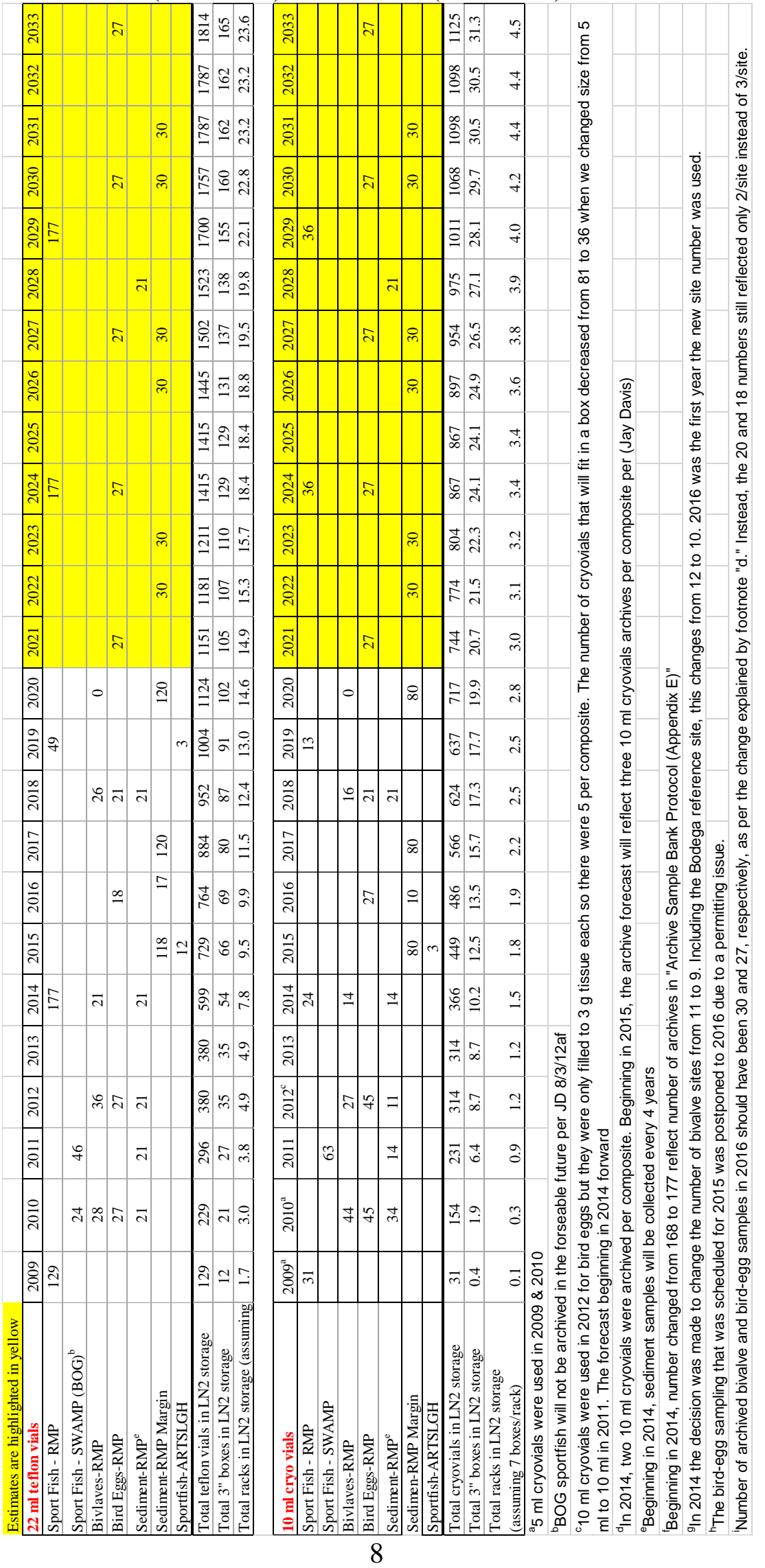


Table 2. Solvent Wash Protocol

\begin{tabular}{|l|c|}
\hline \multicolumn{1}{|c|}{ Reagent Information } & Soak Time \\
\hline Chloroform $(\geq 99.8 \%$ ACS grade) & 1 hour \\
\hline Ethanol $(99.5 \%$ ACS grade) & 1 hour \\
\hline $18.2 \mathrm{M} \Omega$-cm water & rinse \\
\hline Hydrochloric Acid (36.5-38\% ACS grade):18.2 M $\Omega$-cm water $(1: 2)$ & 4 hours \\
\hline $18.2 \mathrm{M} \Omega$-cm water & rinse \\
\hline Nitric Acid $(68-70 \%$ ACS grade):18.2 $\mathrm{M} \Omega$-cm water $(1: 2)$ & 4 hours \\
\hline $18.2 \mathrm{M} \Omega$-cm water & rinse \\
\hline Ethanol $(99.5 \%$ ACS grade) & rinse \\
\hline $18.2 \mathrm{M} \Omega$-cm water & rinse \\
\hline $18.2 \mathrm{M} \Omega$-cm water & rinse \\
\hline
\end{tabular}

Table 3. Sampling Sites for RMP Bivalve Monitoring

\begin{tabular}{|ccccl|}
\hline Site ID & Species Collected & Latitude & Longitude & Location Details \\
\hline T-0 & Mytilus californianus & 38.30482 & -123.06534 & Bodega Head Marine Reserve, reference site \\
BA10 & Mytilus californianus & 37.46983 & -122.06383 & Coyote Creek, near channel marker 18 \\
BA30 & Mytilus californianus & 37.51333 & -122.13467 & Dumbarton Bridge (backup site), near channel marker 14 \\
BA40 & Mytilus californianus & 37.54700 & -122.19500 & Redwood Creek, near channel marker 4 \\
BB71 & Mytilus californianus & 37.69550 & -122.33967 & Alameda (backup site), near channel marker 1 \\
BC10 & Mytilus californianus & 37.81392 & -122.35873 & Yerba Buena Island, east of USCG station \\
BD30 & Mytilus californianus & 38.01667 & -122.36750 & Pinole Point, near channel marker P \\
BD20 & Mytilus californianus & 38.05900 & -122.42367 & San Pablo Bay (backup site), near channel marker 4 \\
BG20 & Corbicula fluminea & 38.05967 & -121.79167 & Sacramento River \\
BG30 & Corbicula fluminea & 38.02117 & -121.80533 & San Joaquin River \\
\hline
\end{tabular}


Table 4. Sampling Sites for RMP Seabird Egg Monitoring

\begin{tabular}{|c|c|c|c|c|}
\hline Site ID & Site Type & Latitude & Longitude & Location Details \\
\hline 2EEPSWI & Cormorant/Historical & 38.08490 & -121.93750 & Wheeler Island \\
\hline 2EEPSRB & Cormorant/Historical & 37.93520 & -122.43730 & Richmond Bridge \\
\hline 2EEPSDEP9/10C & Cormorant/Target & 37.45110 & -122.01170 & Pond A9/10 in Don Edwards NWR \\
\hline 2EPPSDEP16 & Tern/Historical & 37.45120 & -121.96940 & Pond A16 in Don Edwards NWR \\
\hline $\mathrm{A} 2 \mathrm{~W}$ & Tern/Historical & 37.44290 & -122.06900 & Pond A2W in Don Edwards NWR \\
\hline $\mathrm{AB} 2$ & Tern/Historical & 37.43170 & -122.04950 & Pond AB2 in Don Edwards NWR \\
\hline EL & Tern/Historical & 37.58110 & -122.11000 & Eden Landing Ecological Reserve \\
\hline 2EEPSHRS & Tern/Historical & 37.63110 & -122.14590 & Hayward Shoreline Regional Park \\
\hline 2EEPSNM & Tern/Historical & 38.14850 & -122.31550 & Napa-Sonoma Marsh Wildlife Area \\
\hline 2EEPSNCM & Tern/Possible Target & 37.43800 & -121.96800 & New Chicago Marsh \\
\hline 2EEPSPA1 & Tern/Possible Target & 37.43760 & -122.09600 & Pond A1 in Don Edwards NWR \\
\hline 2EEPSPA7 & Tern/Possible Target & 37.44350 & -122.00890 & Pond A7 in Don Edwards NWR \\
\hline HAY3B & Tern/Possible Target & 37.63020 & -122.14680 & Hayward Pond 3B \\
\hline 2EEPSDEP_AB1 & Tern/Possible Target & 37.44430 & -122.06370 & Pond AB1 in Don Edwards NWR \\
\hline
\end{tabular}


Table 5. Sampling Information for Sport Fish Monitoring

\begin{tabular}{|c|c|c|c|c|c|c|}
\hline Common Name & Genus/Species & Gender & Age/Weight & $\begin{array}{c}\text { Number/ } \\
\text { Year } \\
\end{array}$ & $\begin{array}{c}\text { Number/ } \\
\text { Project } \\
\end{array}$ & $\begin{array}{c}\text { Pain } \\
\text { Category* } \\
\end{array}$ \\
\hline Barred sand bass & Paralabrax nebulifer & $\mathrm{M} / \mathrm{F}$ & $2-7 / .2-2 \mathrm{~kg}$ & 220 & 440 & 2 \\
\hline Barred surfperch & Amphistichus argenteus & $\mathrm{M} / \mathrm{F}$ & $2-5 / .1-1 \mathrm{~kg}$ & 515 & 1030 & 2 \\
\hline Bat ray & Myliobatis californica & $\mathrm{M} / \mathrm{F}$ & $2-5 / .5-4 \mathrm{~kg}$ & 110 & 210 & 2 \\
\hline Black \& yellow rockfish & Sebastes chrysomelas & $\mathrm{M} / \mathrm{F}$ & $2-10 / .3-3 \mathrm{~kg}$ & 300 & 600 & 2 \\
\hline Black croaker & Cheilotrma saturnum & $\mathrm{M} / \mathrm{F}$ & $2-5 / .1-1 \mathrm{~kg}$ & 435 & 600 & 2 \\
\hline Black rockfish & Sebastes melanops & $\mathrm{M} / \mathrm{F}$ & $2-10 / .3-3 \mathrm{~kg}$ & 400 & 800 & 2 \\
\hline Black surfperch & Embiotoca jacksoni & $\mathrm{M} / \mathrm{F}$ & $2-5 / .2-1 \mathrm{~kg}$ & 450 & 900 & 2 \\
\hline Blacksmith & Chromis punctipinnis & $\mathrm{M} / \mathrm{F}$ & $2-10 / .3-3 \mathrm{~kg}$ & 300 & 600 & 2 \\
\hline Blue rockfish & Sebastes mystinus & $\mathrm{M} / \mathrm{F}$ & $2-10 / .3-3 \mathrm{~kg}$ & 400 & 800 & 2 \\
\hline Bocaccio & Sebastes paucispinis & $\mathrm{M} / \mathrm{F}$ & $2-10 / .3-3 \mathrm{~kg}$ & 300 & 600 & 2 \\
\hline Bonefish & Albula vulpes & $\mathrm{M} / \mathrm{F}$ & $2-5 / .2-1 \mathrm{~kg}$ & 450 & 900 & 2 \\
\hline Brown rockfish & Sebastes auriculatus & $\mathrm{M} / \mathrm{F}$ & $2-10 / .3-3 \mathrm{~kg}$ & 300 & 600 & 2 \\
\hline Brown smoothhound & Mustelus henlei & $\mathrm{M} / \mathrm{F}$ & $4-8 / 2-10 \mathrm{~kg}$ & 110 & 210 & 3 \\
\hline Butter sole & Isopsetta isolepis & $\mathrm{M} / \mathrm{F}$ & $2-5 / .2-1 \mathrm{~kg}$ & 1000 & 1100 & 2 \\
\hline Cabezon & Scorpaenichthys marmoratus & $\mathrm{M} / \mathrm{F}$ & $2-10 / .5-5 \mathrm{~kg}$ & 100 & 300 & 2 \\
\hline Calico surfperch & Amphistichus koelzi & $\mathrm{M} / \mathrm{F}$ & $2-5 / .1-1 \mathrm{~kg}$ & 515 & 1030 & 2 \\
\hline California corbina & Menticirrhus undulatus & $\mathrm{M} / \mathrm{F}$ & $2-10 / .3-3 \mathrm{~kg}$ & 300 & 600 & 2 \\
\hline California flounder & Paralichthys californicus & $\mathrm{M} / \mathrm{F}$ & $2-10 / .5-5 \mathrm{~kg}$ & 500 & 800 & 2 \\
\hline California grunion & Leuresthes tenus & $\mathrm{M} / \mathrm{F}$ & $2-10 / .5-5 \mathrm{~kg}$ & 500 & 800 & 2 \\
\hline California halibut & Paralichthys californicus & $\mathrm{M} / \mathrm{F}$ & $4-8 / 4-30 \mathrm{~kg}$ & 170 & 340 & 2 \\
\hline California killifish & Fundulus parvipinnis & $\mathrm{M} / \mathrm{F}$ & $2-10 / .3-3 \mathrm{~kg}$ & 300 & 500 & 2 \\
\hline California lizardfish & Synodus lucioceps & $\mathrm{M} / \mathrm{F}$ & $2-10 / .3-3 \mathrm{~kg}$ & 100 & 300 & 2 \\
\hline California scorpionfish & Scorpaena gutta & $\mathrm{M} / \mathrm{F}$ & $2-10 / .3-3 \mathrm{~kg}$ & 400 & 800 & 2 \\
\hline California sheephead & Pimelometopon pulchrum & $\mathrm{M} / \mathrm{F}$ & $2-10 / .5-5 \mathrm{~kg}$ & 400 & 800 & 2 \\
\hline California tonguefish & Symphurus atricaudus & $\mathrm{M} / \mathrm{F}$ & $2-10 / .3-3 \mathrm{~kg}$ & 1000 & 1100 & 2 \\
\hline Canary rockfish & Sebastes pinniger & $\mathrm{M} / \mathrm{F}$ & $2-10 / .3-3 \mathrm{~kg}$ & 300 & 600 & 2 \\
\hline Chilipepper rockfish & Sebastes goodei & $\mathrm{M} / \mathrm{F}$ & $2-10 / .3-3 \mathrm{~kg}$ & 300 & 600 & 2 \\
\hline China rockfish & Sebastes nebulosus & $\mathrm{M} / \mathrm{F}$ & $2-10 / .3-3 \mathrm{~kg}$ & 300 & 600 & 2 \\
\hline Chinook salmon & Oncorhynchus tshawytscha & $\mathrm{M} / \mathrm{F}$ & $4-8 / 4-30 \mathrm{~kg}$ & 170 & 340 & 2 \\
\hline Copper rockfish & Sebastes caurinus & $\mathrm{M} / \mathrm{F}$ & $2-10 / .3-3 \mathrm{~kg}$ & 300 & 600 & 2 \\
\hline Diamond turbot & Hypsopsetta guttulata & $\mathrm{M} / \mathrm{F}$ & $2-10 / .3-3 \mathrm{~kg}$ & 300 & 600 & 2 \\
\hline Dwarf surfperch & Micrometrus minimus & $\mathrm{M} / \mathrm{F}$ & $2-5 / .1-1 \mathrm{~kg}$ & 515 & 1030 & 2 \\
\hline English Sole & Pleuronectes vetulus & $\mathrm{M} / \mathrm{F}$ & $2-10 / .3-3 \mathrm{~kg}$ & 1000 & 1200 & 2 \\
\hline Fantail sole & Xystreurys liolepis & $\mathrm{M} / \mathrm{F}$ & $2-10 / .3-3 \mathrm{~kg}$ & 300 & 600 & 2 \\
\hline Gopher rockfish & Sebastes carnatus & $\mathrm{M} / \mathrm{F}$ & $2-10 / .3-3 \mathrm{~kg}$ & 300 & 600 & 2 \\
\hline Grass rockfish & Sebastes rastrelliger & $\mathrm{M} / \mathrm{F}$ & $2-10 / .3-3 \mathrm{~kg}$ & 300 & 600 & 2 \\
\hline Greenspotted rockfish & Sebastes chlorostictus & $\mathrm{M} / \mathrm{F}$ & $2-10 / .3-3 \mathrm{~kg}$ & 300 & 600 & 2 \\
\hline Grey smoothhound shark & Mustelus californicus & $\mathrm{M} / \mathrm{F}$ & $4-8 / 2-10 \mathrm{~kg}$ & 110 & 210 & 3 \\
\hline Halfmoon & Medialuna californiensis & $\mathrm{M} / \mathrm{F}$ & $2-10 / .3-3 \mathrm{~kg}$ & 300 & 600 & 2 \\
\hline Jack mackerel & Trachurus symmetricus & $\mathrm{M} / \mathrm{F}$ & $2-10 / .3-3 \mathrm{~kg}$ & 300 & 600 & 2 \\
\hline Jacksmelt & Atherinopsis californiensis & $\mathrm{M} / \mathrm{F}$ & $2-5 / .1-1 \mathrm{~kg}$ & 515 & 1030 & 2 \\
\hline Kelp bass & Paralabrax clathratus & $\mathrm{M} / \mathrm{F}$ & $2-10 / .3-3 \mathrm{~kg}$ & 400 & 800 & 2 \\
\hline Kelp greenling & Hexagrammos decagrammus & $\mathrm{M} / \mathrm{F}$ & $2-10 / .3-3 \mathrm{~kg}$ & 300 & 600 & 2 \\
\hline Kelp rockfish & Sebastes artovirens & $\mathrm{M} / \mathrm{F}$ & $2-10 / .3-3 \mathrm{~kg}$ & 300 & 600 & 2 \\
\hline Kelp surfperch & Brachyistius frenatus & $\mathrm{M} / \mathrm{F}$ & $2-5 / .1-1 \mathrm{~kg}$ & 515 & 1030 & 2 \\
\hline Leopard shark & Triakis semifasciata & $\mathrm{M} / \mathrm{F}$ & $4-8 / 2-10 \mathrm{~kg}$ & 110 & 210 & 3 \\
\hline Lingcod & Ophiodon elongatus & $\mathrm{M} / \mathrm{F}$ & $4-8 / 2-10 \mathrm{~kg}$ & 110 & 210 & 2 \\
\hline Longfin sanddab & Citharichthys xanthostigma & $\mathrm{M} / \mathrm{F}$ & $2-5 / .1-1 \mathrm{~kg}$ & 435 & 435 & 2 \\
\hline Northern anchovy & Engraulis mordax & $\mathrm{M} / \mathrm{F}$ & $2-10 / .3-3 \mathrm{~kg}$ & 300 & 500 & 2 \\
\hline Ocean whitefish & Caulolatilus princeps & $\mathrm{M} / \mathrm{F}$ & $2-10 / .3-3 \mathrm{~kg}$ & 300 & 300 & 2 \\
\hline Olive rockfish & Sebastes serranoides & $\mathrm{M} / \mathrm{F}$ & $2-10 / .3-3 \mathrm{~kg}$ & 300 & 600 & 2 \\
\hline Opaleye & Girella nigricans & $\mathrm{M} / \mathrm{F}$ & $2-10 / .3-3 \mathrm{~kg}$ & 300 & 600 & 2 \\
\hline Pacific angel shark & Squatina californica & $\mathrm{M} / \mathrm{F}$ & $4-8 / 2-10 \mathrm{~kg}$ & 110 & 210 & 3 \\
\hline
\end{tabular}


Table 5. Sampling Information for Sport Fish Monitoring (Cont.)

\begin{tabular}{|c|c|c|c|c|c|c|}
\hline Common Name & Genus/Species & Gender & Age/Weight & $\begin{array}{c}\text { Number/ } \\
\text { Year }\end{array}$ & $\begin{array}{c}\text { Number/ } \\
\text { Project }\end{array}$ & $\begin{array}{c}\text { Pain } \\
\text { Category* }\end{array}$ \\
\hline Pacific halibut & Hippoglossus stenolepis & $\mathrm{M} / \mathrm{F}$ & $4-8 / 4-30 \mathrm{~kg}$ & 170 & 400 & 2 \\
\hline Pacific mackerel & Scomber japonicus & $\mathrm{M} / \mathrm{F}$ & $2-10 / .3-3 \mathrm{~kg}$ & 300 & 600 & 2 \\
\hline Pacific sand sole & Psettichthys melanostictus & $\mathrm{M} / \mathrm{F}$ & $2-10 / .3-3 \mathrm{~kg}$ & 1000 & 1200 & 2 \\
\hline Pacific sanddab & Citharichthys sordidus & $\mathrm{M} / \mathrm{F}$ & $2-5 / .1-1 \mathrm{~kg}$ & 515 & 1030 & 2 \\
\hline Pacific sardine & Sardinops sagax caeruleus & $\mathrm{M} / \mathrm{F}$ & $2-10 / .3-3 \mathrm{~kg}$ & 300 & 600 & 2 \\
\hline Pacific staghorn sculpin & Leptocottus armatus & $\mathrm{M} / \mathrm{F}$ & $2-10 / .3-3 \mathrm{~kg}$ & 1000 & 1100 & 2 \\
\hline Pacific whiting & Merluccius productus & $\mathrm{M} / \mathrm{F}$ & $2-10 / .3-3 \mathrm{~kg}$ & 300 & 500 & 2 \\
\hline Pile surfperch & Damalichthys vacca & $\mathrm{M} / \mathrm{F}$ & $2-5 / .1-1 \mathrm{~kg}$ & 515 & 1030 & 2 \\
\hline Queenfish & Seriphus politus & $\mathrm{M} / \mathrm{F}$ & $2-10 / .3-3 \mathrm{~kg}$ & 300 & 600 & 2 \\
\hline Quillback rockfish & Sebastes maliger & $\mathrm{M} / \mathrm{F}$ & $2-10 / .3-3 \mathrm{~kg}$ & 300 & 600 & 2 \\
\hline Rainbow surfperch & Hypsurus caryi & $\mathrm{M} / \mathrm{F}$ & $2-5 / .1-1 \mathrm{~kg}$ & 2000 & 4000 & 2 \\
\hline Redtail surfperch & Amphistichus rhodoterus & $\mathrm{M} / \mathrm{F}$ & $2-5 / .1-1 \mathrm{~kg}$ & 515 & 1030 & 2 \\
\hline Reef surfperch & Micrmetru aurora & $\mathrm{M} / \mathrm{F}$ & $2-5 / .1-1 \mathrm{~kg}$ & 2000 & 4000 & 2 \\
\hline Rosethorn rockfish & Sebastes helvomaculatus & $\mathrm{M} / \mathrm{F}$ & $2-10 / .3-3 \mathrm{~kg}$ & 300 & 600 & 2 \\
\hline Round stingray & Urolophus halleri & $\mathrm{M} / \mathrm{F}$ & $2-7 / .2-2 \mathrm{~kg}$ & 220 & 400 & 2 \\
\hline Rubberlip surfperch & Rhacochilus toxotes & $\mathrm{M} / \mathrm{F}$ & $2-5 / .1-1 \mathrm{~kg}$ & 515 & 1030 & 2 \\
\hline Sablefish & Anoplopoma fimbria & $\mathrm{M} / \mathrm{F}$ & $2-10 / .3-3 \mathrm{~kg}$ & 100 & 300 & 2 \\
\hline Saddleback sculpin & Oligocottus rimensis & $\mathrm{M} / \mathrm{F}$ & $2-10 / .3-3 \mathrm{~kg}$ & 1000 & 1100 & 2 \\
\hline Sargo & Anisotrmus davidsonii & $\mathrm{M} / \mathrm{F}$ & $2-10 / .3-3 \mathrm{~kg}$ & 300 & 500 & 2 \\
\hline Shiner surfperch & Cymatogaster aggregata & $\mathrm{M} / \mathrm{F}$ & $2-5 / .1-1 \mathrm{~kg}$ & 1000 & 4000 & 2 \\
\hline Shovelnose guitarfish & Rhinobatos productus & $\mathrm{M} / \mathrm{F}$ & $4-8 / 2-10 \mathrm{~kg}$ & 110 & 210 & 2 \\
\hline Silver surfperch & Hyperprosopon ellipticum & $\mathrm{M} / \mathrm{F}$ & $2-5 / .1-1 \mathrm{~kg}$ & 515 & 1030 & 2 \\
\hline Speckled sanddab & Citharichthys stigmaeus & $\mathrm{M} / \mathrm{F}$ & $2-5 / .1-1 \mathrm{~kg}$ & 2000 & 4000 & 2 \\
\hline Spiny dogfish & Squalus acanthias & $\mathrm{M} / \mathrm{F}$ & $4-8 / 2-10 \mathrm{~kg}$ & 110 & 210 & 2 \\
\hline Splitnose rockfish & Sebastes diploproa & $\mathrm{M} / \mathrm{F}$ & $2-10 / .3-3 \mathrm{~kg}$ & 300 & 600 & 2 \\
\hline Spotfin croaker & Roncador stearnsii & $\mathrm{M} / \mathrm{F}$ & $2-5 / .1-1 \mathrm{~kg}$ & 515 & 1030 & 3 \\
\hline Spotfin surfperch & Hyperprosopon anale & $\mathrm{M} / \mathrm{F}$ & $2-5 / .1-1 \mathrm{~kg}$ & 515 & 1030 & 2 \\
\hline Spotted sand bass & Paralabrax maculatofasciatus & $\mathrm{M} / \mathrm{F}$ & $2-7 / .2-2 \mathrm{~kg}$ & 500 & 800 & 2 \\
\hline Spotted scorpionfish & Scorpaena guttata & $\mathrm{M} / \mathrm{F}$ & $2-10 / .3-3 \mathrm{~kg}$ & 300 & 600 & 2 \\
\hline Spotted turbot & Pleuronichthys ritteri & $\mathrm{M} / \mathrm{F}$ & $2-10 / .3-3 \mathrm{~kg}$ & 300 & 600 & 2 \\
\hline Starry flounder & Platichthys stellatus & $\mathrm{M} / \mathrm{F}$ & $4-8 / 1-5 \mathrm{~kg}$ & 500 & 600 & 2 \\
\hline Striped bass & Roccus saxatilis & $\mathrm{M} / \mathrm{F}$ & $4-8 / 4-30 \mathrm{~kg}$ & 170 & 340 & 2 \\
\hline Striped mullet & Mugil cephalus & $\mathrm{M} / \mathrm{F}$ & $4-8 / 4-30 \mathrm{~kg}$ & 170 & 340 & 3 \\
\hline Striped sea perch & Embiotoca lateralis & $\mathrm{M} / \mathrm{F}$ & $2-10 / .3-3 \mathrm{~kg}$ & 1000 & 1100 & 2 \\
\hline Striped surfperch & Embiotoca lateralis & $\mathrm{M} / \mathrm{F}$ & $2-5 / .1-1 \mathrm{~kg}$ & 515 & 1030 & 2 \\
\hline Three-spined stickleback & Gasterosteus aculeatus & $\mathrm{M} / \mathrm{F}$ & $2-10 / .3-3 \mathrm{~kg}$ & 1000 & 1100 & 2 \\
\hline Thresher shark & Alopias vulpinus & $\mathrm{M} / \mathrm{F}$ & $4-8 / 4-30 \mathrm{~kg}$ & 30 & 60 & 3 \\
\hline Topsmelt & Atherinops affinis & $\mathrm{M} / \mathrm{F}$ & $2-5 / .1-1 \mathrm{~kg}$ & 515 & 1500 & 2 \\
\hline Vermillion rockfish & Sebastes miniatus & $\mathrm{M} / \mathrm{F}$ & $2-10 / .3-3 \mathrm{~kg}$ & 300 & 600 & 2 \\
\hline Walleye surfperch & Hyperprosopon argenteum & $\mathrm{M} / \mathrm{F}$ & $2-5 / .1-1 \mathrm{~kg}$ & 515 & 1030 & 2 \\
\hline White croaker & Genyonemus lineatus & $\mathrm{M} / \mathrm{F}$ & $2-5 / .1-1 \mathrm{~kg}$ & 515 & 1030 & 2 \\
\hline White surfperch & Phanerodon furcatus & $\mathrm{M} / \mathrm{F}$ & $2-5 / .1-1 \mathrm{~kg}$ & 515 & 1030 & 2 \\
\hline Widow rockfish & Sebastes entomelas & $\mathrm{M} / \mathrm{F}$ & $4-8 / 4-30 \mathrm{~kg}$ & 100 & 340 & 2 \\
\hline Yellowfin croaker & Umbrina roncador & $\mathrm{M} / \mathrm{F}$ & $2-5 / .1-1 \mathrm{~kg}$ & 515 & 1030 & 2 \\
\hline Yellowtail rockfish & Sebastes flavidus & $\mathrm{M} / \mathrm{F}$ & $2-10 / .3-3 \mathrm{~kg}$ & 300 & 600 & 2 \\
\hline
\end{tabular}

* Pain category 2 indicates no procedure is expected to cause more than momentary or slight pain and distress. Pain category 3 indicates more distress may be caused, and includes those species potentially caught by gill net. 
Table 6. Summary of SFEI specimens archived at the NIST Biorepository (2009-2020)

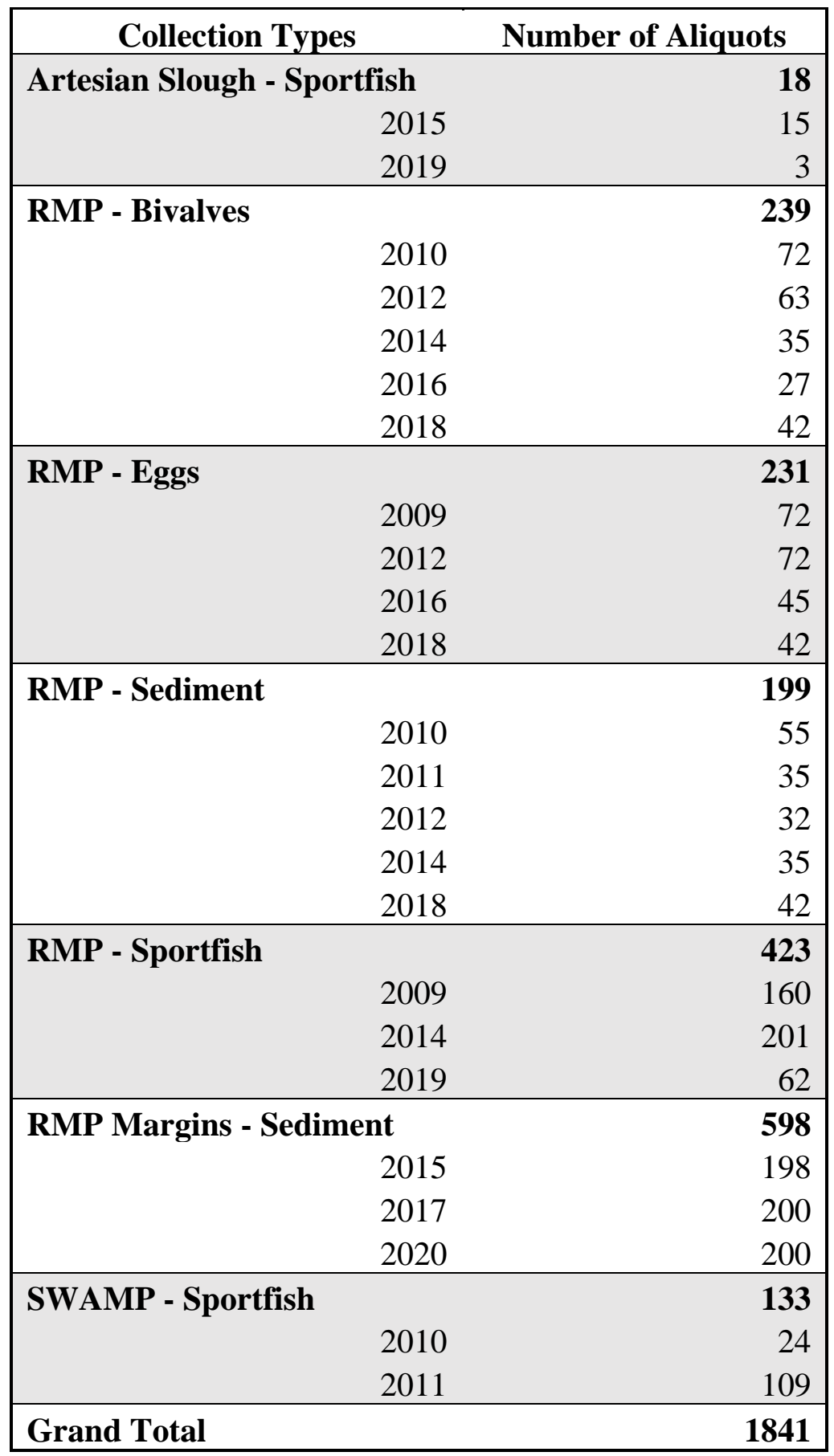




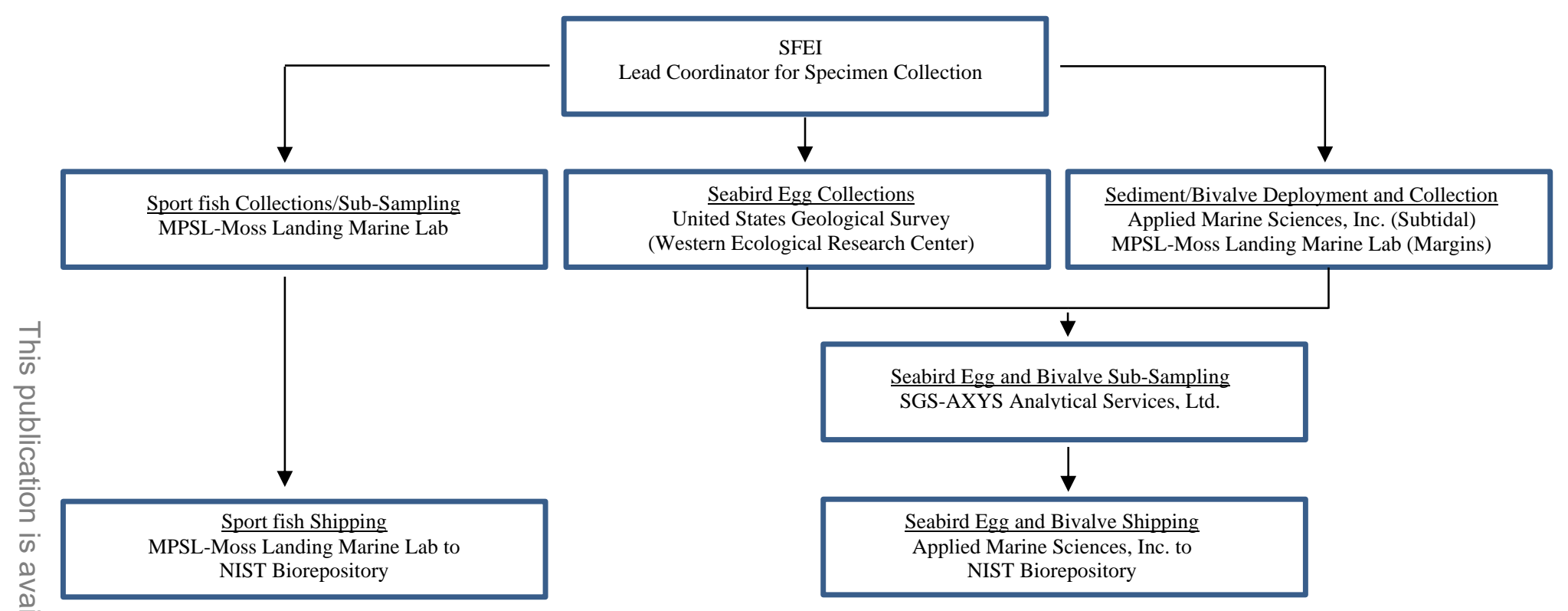

Figure 1. Principle SFEI Collaborators and Responsibilities

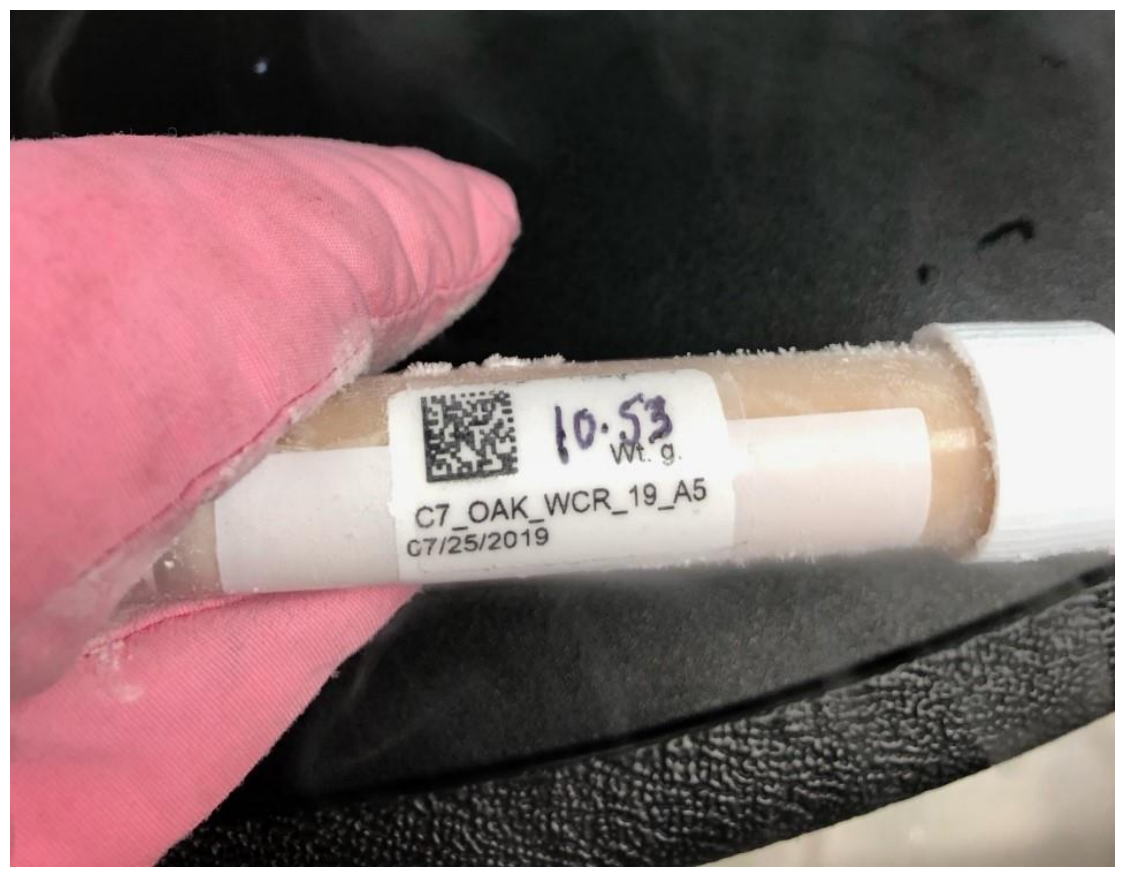

Figure 2. Cryovial with barcode label appropriately applied 


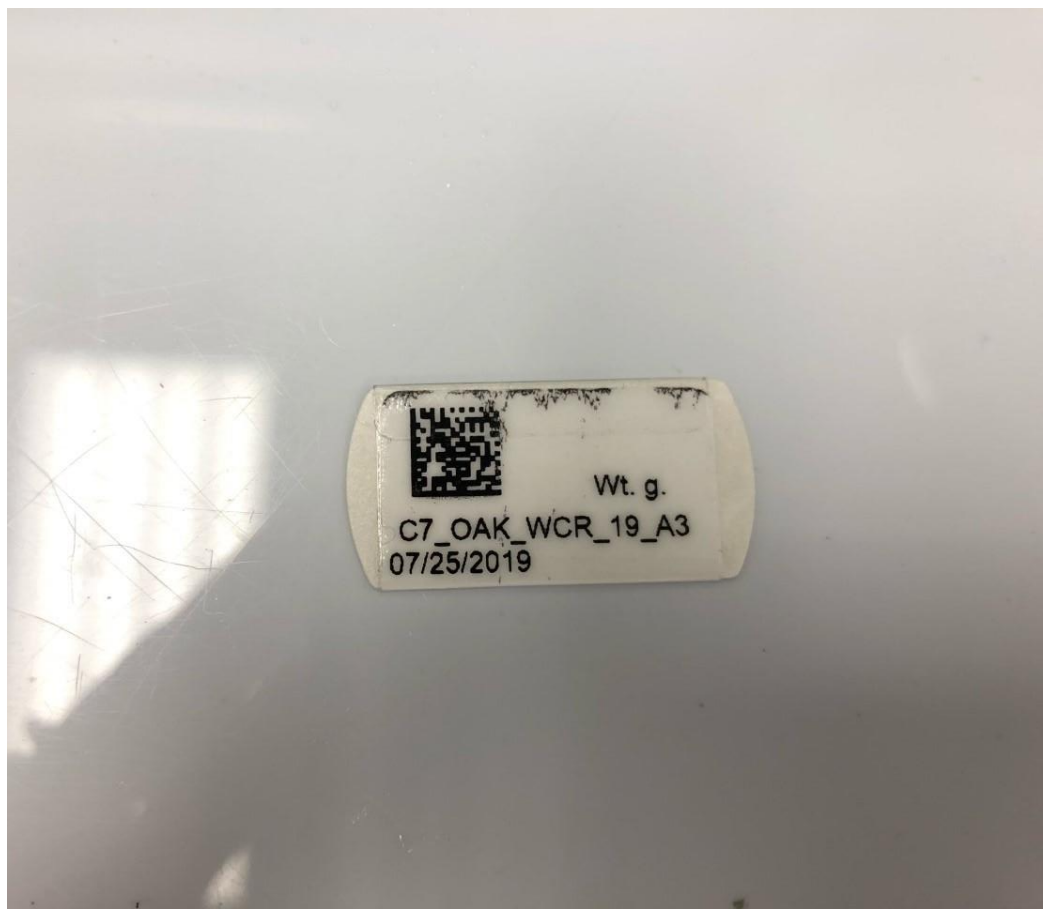

Figure 3. PFA jar lid tab with barcode label appropriately applied

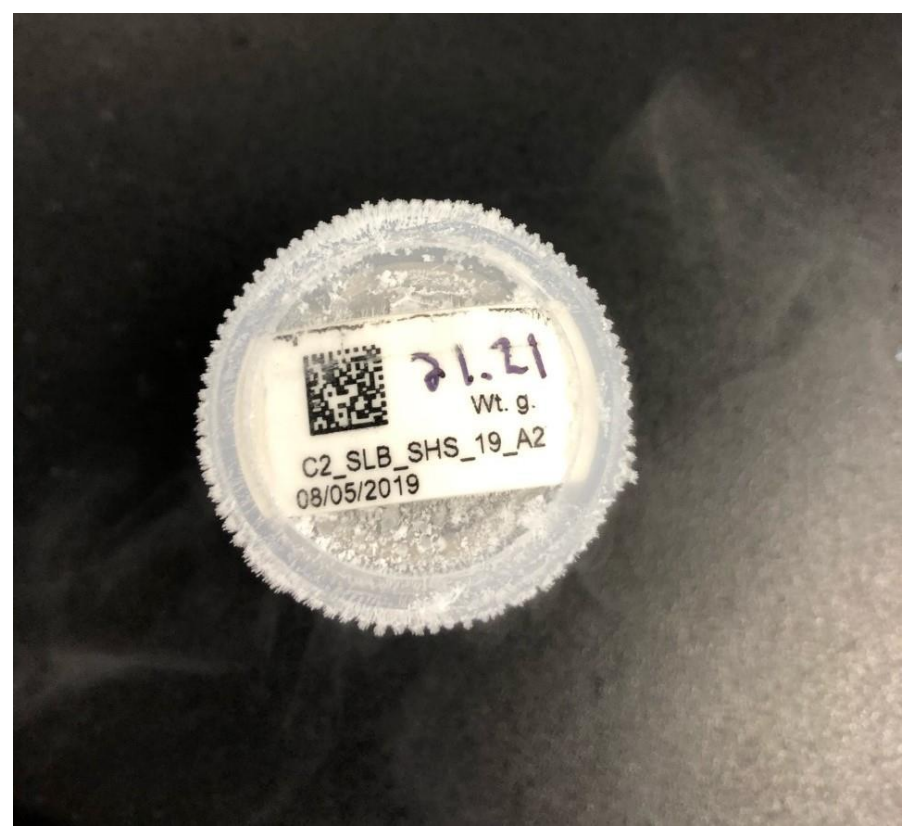

Figure 4. PFA jar with barcoded tab appropriately inserted into the lid 


\section{Acknowledgments}

Thank you to Paul Salop of AMS for reviewing this document and providing helpful comments.

\section{References}

1. Wise, S.A. and B.J. Koster, Considerations in the design of an environmental specimen bank - experience of the National Biomonitoring Specimen Bank Program. Environmental Health Perspectives, 1995. 103: p. 61-67.

2. McFarland, M., Assessment of the integrity of chemicals in environmental samples over an extended period of time, E. Canada, Editor. 1996: Vancouver, British Columbia. p. 58.

3. Ackerman, J.T., M.P. Herzog, and S.E. Schwarzbach, Methylmercury is the Predominant Form of Mercury in Bird Eggs: A Synthesis. Environmental Science \& Technology, 2013. 47(4): p. 2052-2060. 